\title{
Determinants of Employee Performance with Work Motivation as an Intervening Variable at the Semarang City Search and Rescue Office
}

\author{
Widhy Setyowati ${ }^{1}$, Aris Sofingi ${ }^{2}$ \\ 1,2STIE Bank BPD, CentralJava \\ e-mail: widhisetyowati61@gmail.com ${ }^{1}$, sofingiaris@gmail.com²
}

\section{To cite this document :}

Setyowati, W., \& Sofingi, A. (2022). Determinants of Employee Performance with Work Motivation as an Intervening Variable at the Semarang City Search and Rescue Office. Aptisi Transactions on Management (ATM), 6(1), 19-29.

DOI :

https://doi.org/10.33050/atm.v6i1.1638

\begin{abstract}
Employees are the main key in increasing productivity and the success of agency activities. Employees have an important role in reducing or minimizing the impact of loss or damage caused by a disaster. This study aims to analyse and empirically test the influence of leadership on employee work motivation, organizational culture on employee work motivation, leadership on employee performance, organizational culture on employee performance, work motivation on employee performance, work motivation in mediating the influence of leadership on employees. performance, and work motivation in mediating the influence of organizational culture on employee performance. The method in this study using the sampling method, the population in this study is the SAR Department of Semarang City. The research sample was 125 samples. The results show that leadership has a positive effect on work motivation, organizational culture has a positive effect on work motivation, leadership has a positive effect on performance, organizational culture has a positive effect on performance, work motivation has a positive effect on performance, leadership has a positive effect on performance through work motivation, and culture organization has a positive effect on performance through work motivation. The conclusion from the results of this study is that the leadership that has been carried out has a positive impact on employees at the Semarang City Search and Rescue Service.
\end{abstract}

Keywords: Leadership, Organizational Culture, Employee Performance, Work Motivation

\section{Introduction}

The National Search and Rescue Agency or known as BASARNAS, is a non-ministerial government agency that has tasks in the field of search and rescue (SAR). Clearly, the duties and functions of SAR include handling shipping and / or aviation disasters, and / or other disasters and / or calamities in search and rescue efforts when a disaster occurs.

It is also very important in an agency, namely employees. In every agency activity, employees are the main key in increasing the productivity and success of the agency's activities [1]. The Search and Rescue Office is no exception, where employees have an important role to play in reducing or minimizing the impact of loss or damage caused by a disaster. Therefore, improving the performance of the Search and Rescue Office employees is urgently needed.

Employee performance is related to the quality and quantity of work performed by employees as well as relating to the conditions of employees in certain organizations [2]. Good performance is performance that supports the achievement of goals and according to organizational standards. Based on the Performance Report of the National SAR Agency, the 
response time (response time) in handling shipping accidents and other accidents still exceeds the set target, which is 30 minutes.

Based on the performance data, it is known that for ship accident handling operations, conditions endanger humans, and so special handling takes way more than 30 minutes [3]. This shows that the performance of the Search and Rescue Office is not optimal, so it is necessary to investigate the factors that cause the long response time and travel time in handling accidents.

One of the efforts to improve the performance of the Search and Rescue Office employees is to increase work motivation [4]. With work motivation for each employee, the employees will give their best performance for the agency voluntarily. Employees must have good work motivation, bearing in mind that the task carried out is not an easy task. Employees are tasked with mapping prevention and mitigation, even having to deal with disasters and damage or loss due to disasters. Without a good work motivation drive, of course the performance given will not be optimal

Work inspiration contains a noteworthy positive impact on making strides in representative execution [5]. Worker work inspiration in creating assignments that are carried out is decided by the measure of the obligation given to the worker. Based on inquire about [6] work inspiration has no impact on worker performance. Planting work inspiration is considered inconsequential for the requirements of employees' presence and development so that it does not have a significant effect on moving forward representative execution. Teaching work inspiration is considered inconsequential for the requirements of employees' presence and development so that it does not have a noteworthy impact on moving forward representative performance.

One of the factors that plays an important role in increasing employee motivation is the leadership of a leader. Leadership is the key between success or failure for organizations. In an organization, the traits and leadership attitudes of a leader to influence others are crucial in achieving organizational goals. The leadership factor becomes very important because it is the leader who will move and direct the organization in achieving its goals, which is a difficult task. Leaders must understand each different behaviour of their members [7].

Based on the research [8] the results show that leadership has a significant positive effect on increasing employee motivation [9]. Good leadership will provide positive encouragement to employees so that employees are motivated to do their job optimally. The results of the research [10] show that leadership cannot directly affect employee performance, but it requires a mediating role in work motivation. This means that a good leadership attitude has a positive influence in motivating employees to give their best performance in order to achieve organizational goals.

Apart from leadership, a factor that plays an important role in increasing employee motivation is organizational culture. Organizational culture is the values developed in an organization, where these values are used to direct the behaviour of employees [11]. Organizational culture influences work motivation positively and significantly, where the more conducive the relationship between the leader and its members, the relationship between fellow employees, and the support of the organization's management environment, the more comfortable it is in the work environment so that it can encourage employee work motivation [12][13]. The increase in work motivation felt by employees will have an impact on improving employee performance.

Organizational culture has a significant positive effect on work motivation, where improvements in organizational culture have an impact on increasing motivation for employees. This result contradicts the results of [14] research which found that organizational culture has no influence on work motivation.

Organizational performance is highly dependent on individual performance in an organization. When individuals in an organization are able to work effectively, the organizational performance will be effective. Individual performance is the main key in measuring organizational performance. Personal factors such as a leader's leadership attitude towards employees and the scope of organizational culture applied to employees greatly affect individual performance. These factors can be a motivation for employees to improve individual performance so that organizational performance becomes better. Based on the problems and research gaps described above, researchers are interested in exploring employee performance from the perspective of leadership and organizational culture through work motivation interventions.

\section{Leadership}

ATM Vol 6, No. 1 January 2022: 19-29 
Leadership literally comes from the word pimpin, which means guiding, directing, guiding and also informing or influencing. Leaders have responsibility both morally and spiritually for the ability of the work activities of the organization they lead. Thus, the leader is not easy and not everyone has the ability to carry out his leadership. Leadership is a way or technique of influencing the behaviour of other people, both individuals and groups. Furthermore, [15] states that leadership is a way of influencing employee behaviour, so that they are willing to work together in achieving organizational goals. Based on this definition, leadership is a person's skills in influencing, directing, spurring, encouraging and controlling employees, to be able to work on a project on an initiative taken sincerely in achieving certain targets.

In general, the state of the internal organization greatly influences the implementation of leadership. In this connection, in this case it will explain the description of other forms of leadership implementation that can be carried out simultaneously. In planning work based on employee maturity level, there are four forms of leadership, namely directing, selling, mobilizing, participating and commanding.

\section{Organizational Culture}

According to [16], organizational culture is a system of beliefs, values and norms that are developed within the organization and serve as guidelines for the behaviour of organizational members. This organizational culture provides guidelines for employees. Some of the important roles of organizational culture are: (a) helping to develop a sense of belonging; (b) is used to develop personal attachments to the organization; (c) helps social balance; and (d) presents a code of conduct as a result of established norms of behaviour. A culture that grows strong triggers the organization to develop [17].

[18] mentions 7 cultural dimensions, particularly human family members with nature, time orientation, individualism as opposed to collectivism, informality, interest orientation, language, and beliefs. Meanwhile, the size that may be used to distinguish organizational subculture is based [19] on seven characteristics, particularly: (1) innovation and hazard taking; (2) interest to greater element, the quantity to which personnel examines in element in greater element; (3) consequences orientation, the quantity to which control will recognition on cons equences, now no longer on strategies and strategies to attain those consequences; (4) humans orientation, the quantity to which choices from control will gain individuals withinside the employer; (5) group orientation, completed or prepared in an operating group, now no longer people or people; (6) aggressiveness, the quantity to which someone or member of an employer is competitive and competitive, now no longer simply relaxing; and (7) balance in sporting out the entirety that has been planned.

\section{Work Motivation}

Motivation is described as a condition or force that encourages employees to be directed or targeted in order to achieve organizational goals [20]. The energetic mental attitude of each employee that strengthens work to achieve maximum performance [21]. In addition, motivation also means the entire process of motivating employees to work well so that they want to do their job well in order to achieve organizational goals with efficient and economical principles. Thus, in general motivation is part of individual orientation [22].

This individual orientation can be placed as an important matter of a management activity, so that it can be aimed at optimizing the abilities of each member by increasing enthusiasm and energy so that all tasks, either individually or in groups, can be carried out well. There are two aspects of motivation, namely: 1) dynamic or active aspects, motivation is seen as an effort to mobilize, direct the potential of members to be more productive and aggressive in achieving organizational goals; 2 ) the passive or static aspect, motivation will emerge as a need and also as a motivator in order to encourage the ability and enthusiasm of members.

\section{Performance}

Performance in a company is an element in an organization, both public and private. Performance is a work achievement achieved by a person [23][24][25]. According to [26], employee performance is the level of success of employees in carrying out tasks. Performance is very important to and will encourage someone to be better at achieving goals [27][28]. So, it can be concluded that performance is the result of individual work that has been done correctly in accordance with the responsibilities given in a certain period of time [24][29]. 
[30] explains about the balanced scorecard as a performance theory, namely a concept developed by Robert S. Kaplan and David P. Norton in 1992. This concept is relatively the same as that developed in France called the tableau de bord or dashboard which identifies four areas as triggers for company success, namely in logistics, manufacturing, personnel and administration. The Balanced Scorecard is a group of integrated performance benchmarks derived from the company's business strategy. For this reason, top management must define the company's strategy into performance benchmarks that must be understood and implemented by all employees. The description is divided into 4 perspectives, namely: (1) financial perspective; (2) consumer or customer perspective; (3) internal business process perspective; and (4) human resources learning perspective.

\section{Research Method}

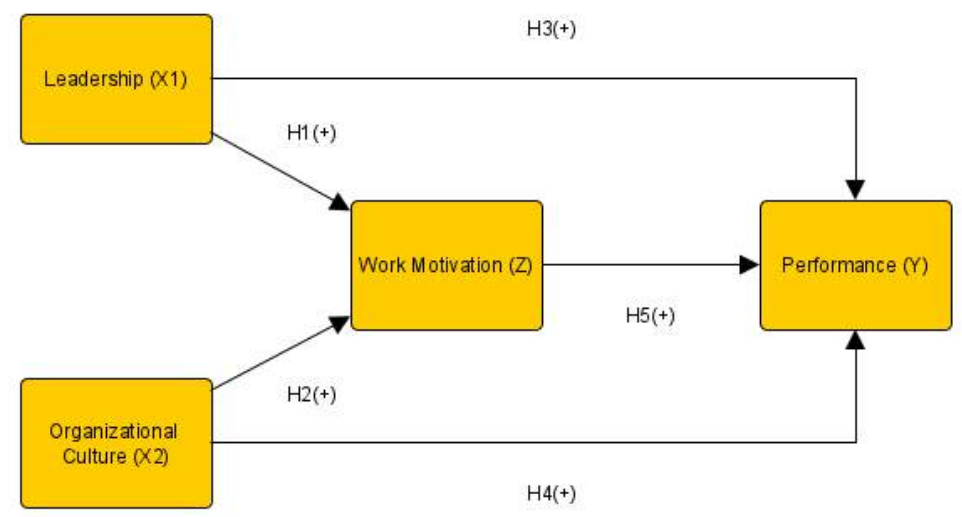

Figure 1. Research Model

\section{Population and Sample}

In this study the population taken was the Semarang City Search and Rescue Office. The sample used is saturated sampling technique or census, where all members of the population are sampled. So that all 125 employees of the Semarang City Search and Rescue Office were sampled.

\section{Data Collection Technique}

To obtain data from various data sources, the researchers used several methods for data retrieval. This research data using a questionnaire data collection tool (survey). The researcher gave a questionnaire to the employees of the Semarang City Search and Rescue Office. The answers to the questions that the respondent will fill are made on a Likert scale, namely by using a range of 1 to 5 , the value of 1 is very inappropriate / agree, and the value of 5 is very suitable / agree.

\section{Validity and Reliability Testing}

Validity, which means the accuracy and accuracy of the bias to what extent in the measuring instrument letter to perform the measurement function [31]. In a test, it can be said to have a high result if the test is able to carry out its measuring function, or provide measurement results, which are precise and in accordance with the purpose of the test in question. In testing the validity, it used Factor Analysis which was processed using the SPSS computer program.

The criteria for testing the Kaiser-Mayer-Olkin Odecuary Value (Kaiser's MSA) with a signal for the data to be collected and correctly carried out. Factor analysis is above 0.50 and this also shows the Construct Validity of each Variable Item included in the final analysis is that which has a factor loading more than 0.40 [32].

Reliability is a measure that can be understood and relied on to show the extent of the index. In this test $\alpha$ is considered reliable if it is $>0.7$ [32]. This calculation will be carried out with the help of the SPSS computer. The results of the calculation show that it is reliable if the alpha coefficient is greater than 0.7 , it means that the questionnaire is reliable and can be used for research. 


\section{Model Feasibility Test Coefficient of Determination}

To test this research model is to calculate the coefficient of determination (R2) here which is measured is how to explain the dependent variation through the measure of the ability of the model. The coefficient of determination is between zero and one [32]. The greater the R2, the independent variable shows the more dominant influence on the dependent variable, and the free variable has the biggest $\mathrm{R} 2$, which shows the depend ent variable is the most dominant.

$\mathrm{R} 2$ is a quantity that is defined as the coefficient of termination (sample) and part of the common quantity used as a measure of goodness of fit the regression line. $R 2$ verbally measures the share of the total variation in $\mathrm{Y}$ which is explained using a regression model.

\section{Anova test}

The variable here in the $\mathrm{F}$ test is aimed at whether it is free to include in the model that jointly affects the dependent variable [32]. The model is said to be Fit, if the probability value is significant less $5 \%$.

\section{Hypothesis test}

The $t$ test is to test the acceptance and rejection of the hypotheses tested in this study. This test is shown by the extent of the influence of the independent variable individually to explain the variation in the dependent variable [32]. Testing by looking at the maximum error of the test results, if the maximum error ( $\mathrm{Sig}$ ) is less than $5 \%$ then the tested hypothesis can be accepted [32].

\section{Mediation Testing}

In this study, to test the effect of intervening variables, a path analysis was used, which is an extension of multiple regression analysis. Path analysis is used here as a regression analysis as an estimate of the theory-based causality relationship with the determination of existing variables. This relationship according to the theoretical basis has been formed with a model that can be done using path analysis using a pattern of relationships from several variables [32].

A direct relationship occurs when there is influence from one variable to another and there are no other variables as a mediator (intervening). An indirect relationship occurs if there is a mediator in the relationship between the two variables by determining the multiplication result between the standardized values of the independent variable to the mediating variable and the mediating variable to the dependent variable. If the direct regression path coefficient is greater than the indirect calculation (using mediation), it can be said that the relationship is a direct relationship, and vice versa.

\section{Results and Analysis Descriptive statistics}

Respondents of this study were all employees of the Semarang Search and Rescue Office. In this study, 125 questionnaires were distributed according to the number of employees of the Semarang Search and Rescue Office. All questionnaires distributed were returned by the employee. Of the 125 returned questionnaires, 23 questionnaires were eliminated because there were missed or multiple answers, so the questionnaire that could be used was 102 . Thus, the return rate of the questionnaire was $100 \%$ and the usable rate of return was $81.60 \%$. A summary of the questionnaire returns is presented in the following table.

Table 1. Questionnaire Return Rate

\begin{tabular}{|l|c|}
\hline Distributed questionnaires & 125 \\
\hline The questionnaire was not returned & 0 \\
\hline Questionnaires returned & 125 \\
\hline Eliminated Questionnaire & 23 \\
\hline Questionnaire used & 102 \\
\hline Rate of return (respond rate) & $\mathbf{1 0 0 \%}$ \\
\hline
\end{tabular}

Determinants of Employee Performance with Work Motivation as an Intervening Variable at the Semarang City Search and Rescue Office (Widhy Setyowati) 


\begin{tabular}{|l|c|}
\hline Rate of return used (usable respond rate) & $\mathbf{8 1 , 6 0 \%}$ \\
\hline Source: Primary Data Processed, 2020 &
\end{tabular}

From 102 questionnaires that have been distributed to employees generate hypotheses. The following 7 hypotheses were generated:

\section{The Influence of Leadership on Work Motivation}

Theory 1 proposed in this ponder is that administration encompasses a positive impact on work inspiration. In other words, the higher the administration values connected by the authority of the Semarang Look and Help Office, the higher the work inspiration felt by representatives in that organization. The comes about of the measurable testing of speculation 1 appear that the noteworthiness esteem is littler than alpha 0.05 so that theory 1 is acknowledged.

Based on the comes about of testing for speculation 1, this ponder succeeded in finding a noteworthy impact of authority on work inspiration in a positive course. In this way, theory 1 is acknowledged. The higher the authority values connected by the administration, the higher the work inspiration felt by employees.

The comes about of testing for speculation 1 are in understanding with past inquire about conducted by [8] which concluded that authority incorporates a noteworthy positive impact on work inspiration. In common, administration demeanours incredibly influence representative inspiration. A pioneer who can make himself a great case and part show for workers will impact the employee's point of see at work, and make the pioneer ended up a part demonstrate. Pioneers who are willing to listen thoughts from workers some time recently making a choice will make representatives have a strong motivation to work [33], so that work isn't a burden but a commitment that must be completed intentionally in arrange to attain organizational goals.

The test results are in accordance with the hypothesis, that the implementation of good leadership will create a good work motivation. Based on research data, most respondents agree that the value of good leadership at the Semarang Search and Relief Office will create good work motivation as well. This shows that in general the leadership of a leader in the Semarang Search and Relief Office has a strong influence in influencing employee motivation.

\section{The Influence of Organizational Culture on Work Motivation}

Hypothesis 2 proposed in this study is that organizational culture has a positive effect on work motivation. In other words, the higher the work culture values that are applied to the Semarang Search and Relief Office, the higher the work motivation felt by employees in that agency. The results of statistical testing of hypothesis 2 show that the significance value is smaller than alpha 0.05 , so that hypothesis 2 is accepted.

Based on the results of testing for hypothesis 2, this study succeeded in finding a significant effect of organizational culture on work motivation in a positive direction. Thus, hypothesis 2 is accepted. The higher the work culture values applied by the agency, the higher the work motivation felt by employees.

The results of testing for hypothesis 2 are in accordance with previous research conducted by [34] who concluded that organizational culture has a significant positive effect on work motivation. The creation of a good culture in an organizational environment is an important key in the formation of good work motivation for employees. A good culture in an organization will make the work environment comfortable to work. With a good atmo sphere and culture between leaders and employees, as well as between employees and each other, it will create comfort in working so that employees see a job not as a burden but an obligation that must be completed voluntarily in order to achieve organizational goals. By creating a good organizational culture in an organization, employees will be motivated to do their best in completing their work.

The test results are in accordance with the hypothesis, that the implementation of a good organizational culture will create a good work motivation. Based on research data, most respondents agree that the values of good organizational culture in the Semarang Search and Relief Office will create good work motivation as well. This shows that in general the work cult ure at the Semarang Search and Relief Office has a strong influence in influencing employee motivation.

\section{The Influence of Leadership on Performance}


Hypothesis 3 proposed in this study is that leadership has a positive effect on performance. In other words, the higher the leadership values applied by the leadership of the Semarang Search and Relief Office, the higher the performance of employees in that agency. The results of statistical testing of hypothesis 3 show that the significance value is smaller than alpha 0.05 , so that hypothesis 3 is accepted.

Based on the results of testing for hypothesis 3 , this study succeeded in finding a significant influence of leadership on performance in a positive direction. Thus, hypothesis 3 is accepted. The higher the leadership values applied by the leader, the higher the employee's performance.

The results of testing for hypothesis 3 are in accordance with previous research conducted by [35] which concluded that leadership has a significant positive effect on employee performance. Leaders in an organization must have advantages over their employees, so that leaders have the authority to mobilize employees without coercion and so that employees can work under the leader's command with a full sense of responsibility and without being forced. The leadership attitude of a leader is one of the keys to the success of an organization, because a leader is someone who manages the employees to move to achieve organizational goals. The better the leadership of a leader, the better he will be able to manage his employees to work effectively and efficiently in accordance with the abilities of each employee so that employee performance will also increase.

The test results are in accordance with the hypothesis, that the implementation of good leadership will result in good performance. Based on research data, most respondents agree that good leadership values at the Semarang Search and Rescue Office will result in good performance as well. This shows that in general the leadership of a leader in the Semarang Search and Relief Office has a strong influence in influencing employee performance.

\section{The Influence of Organizational Culture on Performance}

Hypothesis 4 proposed in this study is that organizational culture has a positive effect on performance. In other words, the higher the work culture values that are applied to the Semarang Search and Rescue Office, the higher the employee's performance in that agency. The results of statistical testing of hypothesis 4 show that the significance value is smaller than alpha 0.05 , so that hypothesis 4 is accepted.

Based on the results of testing hypothesis 4 , this study was able to find a significant influence of organizational culture on performance in a positive direction. Thus, hypothesis 4 is accepted. The higher the work culture values applied by the agency, the higher the employee's performance.

The results of testing for hypothesis 4 are in accordance with previous research conducted by [34] which concluded that organizational culture has a significant positive effect on employee performance. Organizational culture becomes a code of conduct for its members which is unconsciously applied in carrying out organizational activities. The importance of organizational culture in relation to employee performance. that in reality, one of the organizational culture studies suggests that employees in companies or institutions with strong cultures are more responsible for the performance of their company or agency than employees in companies or institutions with weak cultures. Companies or agencies with strong cultures will also use their training efforts and outreach practices to build employee performance.

The test results are in accordance with the hypothesis, that the implementation of a good organizational culture will result in good performance. Based on research data, most respondents agree that the values of a good organizational culture at the Semarang Search and Relief Office will result in good performance as well. This shows that in general the work culture at the Semarang Search and Rescue Office has a strong influence in influencing employee performance.

\section{Effect of Work Motivation on Performance}

Hypothesis 5 proposed in this study is that work motivation has a positive effect on performance. In other words, the higher the work motivation of the Semarang Search and Rescue Office employees, the higher the employee's performance in that agency. The results of statistical testing of hypothesis 5 show that the significance value is smaller than alpha 0.05 , so that hypothesis 5 is accepted. 
Based on the results of testing for hypothesis 5 , this study succeeded in finding a significant effect of work motivation on performance in a positive direction. Thus, hypothesis 5 is accepted. The higher the work motivation felt by employees, the higher the employee's performance.

The results of testing for hypothesis 5 are in accordance with previous research conducted by [5] which concluded that work motivation has a significant positive effect on employee performance. Employees who work in a company or agency with high work motivation will produce good performance because of a sense of responsibility to carry out work with full awareness. Employees who do not have work motivation cannot work optimally, effectively or efficiently because work motivation is the driving force that becomes a reason for someone to do something. Positive and strong work motivation is the key to the success of achieving performance and achieving organizational goals. With positive and strong work motivation in employees, employees will be moved to always improve performance and always provide the best performance for the company or institution where they work.

The test results are in accordance with the hypothesis, that good work motivation will result in good performance. Based on research data, most respondents agree that good work motivation at the Semarang Search and Relief Office will result in good performance as well. This shows that in general work motivation at the Semarang Search and Relief Office has a strong influence in influencing employee performance.

\section{The Influence of Leadership on Performance Through Work Motivation}

Hypothesis 6 proposed in this study is that leadership has a positive effect on performance through work motivation. In other words, the higher the leadership values applied by the leaders of the Semarang Search and Relief Office, the higher the employee's work motivation, and the higher the work motivation of the Semarang Search and Help Office employees, the higher the performance in that agency.

Based on the results of statistical analysis, it is known that the direct effect of leadership on employee performance is 0.454 . While the indirect effect of leadership on employee performance through work motivation is the multiplication of the beta value of leadership on work motivation and the beta value of work motivation on performance, namely $0.310 \times 0.401=0.124$. Based on the results of these calculations, it is known that the direct effect is 0.454 and the indirect effect is 0.124 . The indirect effect is smaller than the direct effect, so hypothesis 6 which states that leadership has a positive effect on employee performance through work motivation is not proven in this study.

The test results are not in accordance with the hypothesis proposed, that good leadership will create good work motivation and good work motivation will result in good performance. Based on the results of testing for hypothesis 6 , this study did not find any significant influence of leadership on employee performance through work motivation. Thus, hypothesis 6 is rejected. Work motivation does not mediate the influence of leadership on the performance of the Semarang Search and Rescue Office employees.

\section{The Influence of Organizational Culture on Performance Through Work Motivation}

Hypothesis 7 proposed in this study is that organizational culture has a positive effect on performance through work motivation. In other words, the higher the work culture values applied by the Semarang Search and Help Office, the higher the employee's work motivation, and the higher the work motivation of the Semarang Search and Help Office employees, the higher the performance in that agency.

Based on the comes about of factual investigation, it is known that the coordinate impact of organizational culture on worker execution is 0.404 . Whereas the backhanded impact of organizational culture on worker execution through work inspiration is the increase of the beta esteem of organizational culture on work inspiration and the beta esteem of work inspiration on execution, specifically $0.196 \times 0.401=0.079$. Based on the comes about of these calculations, it is known that the coordinate impact is 0.404 and the backhanded impact is 0.079 . The roundabout impact is littler than the coordinate impact, so theory 7 which states that organizational culture incorporates a positive effect on representative execution through work inspiration isn't demonstrated in this study.

The test comes about are not in agreement with the theory, that a great organizational culture will make great work inspiration and great work inspiration will result in great execution. 
Based on the comes about of testing for speculation 7, this consider did not discover any noteworthy impact of organizational culture on representative execution through work inspiration. In this way, speculation 7 is rejected. Work inspiration does not intervene the impact of organizational culture on worker execution within the Semarang Look and Help Office.

\section{Conclusion}

So, the problems that occur are the factors that determine leadership in influencing the increase in employee work motivation at the Semarang City BASARNAS Service.

Based on the results of the questionnaire, there are 7 conclusions as follows:

1) Leadership directly has a positive influence on work motivation. These results indicate that the work motivation of the Semarang Search and Relief Office employees can be improved by implementing good leadership values.

2) Organizational culture directly has a positive influence on work motivation. These results indicate that the work motivation of Semarang Search and Relief Office employees can be improved by implementing a good org anizational culture.

3) Leadership directly has a positive influence on employee performance. These results indicate that the performance of the Semarang Search and Relief Office employees can be improved by implementing good leadership values.

4) Organizational culture directly has a positive influence on employee performance. These results indicate that the performance of the Semarang Search and Rescue Office employees can be improved by implementing a good organizational culture.

5) Work motivation directly has a positive influence on employee performance. These results indicate that the performance of the Semarang Search and Rescue Office employees can be improved by keeping the employees' work motivation in good condition.

6) Work motivation does not mediate the influence of leadership on the performance of employees of the Semarang Search and Relief Office. These results indicate that work motivation is not related to increasing leadership values and improving employee performance in the Semarang Search and Rescue Office.

7) Work motivation does not mediate the influence of organizational culture on employee performance in the Semarang Search and Relief Office. These results indicate that work motivation is not related to improving organizational culture and improving employee performance in the Semarang Search and Relief Office.

The limitation experienced during compiling this research is the method of datacollection. This study only collects data using a closed questionnaire, so there is a chance that the results of this study do not describe the realities that occur in the field.

Because there are still limitations in this study, suggestions for future research improvements are expected to add data collection methods in the form of open questionnaires or interviews, so that opinions and aspirations of respondents can be more conveyed in order to achieve employee performance and agency performance to be better.

\section{References}

[1] Q. Aini, E. P. Harahap, and F. Faradilla, "The Effects of Sales Reports Business Intelligence on Employee Performance," Aptisi Trans. Manag., vol. 4, no. 1, pp. 83-91, 2019.

[2] U. Rahardja, Q. Aini, and A. Khoirunisa, "Effect of iDu (iLearning Education) on Lecturer Performance in the Lecture Process," Aptisi Trans. Manag., vol. 2, no. 2, pp. 140-148, 2018. 
[3] O. A. V. Banda and F. Goerlandt, "A STAMP-based approach for designing maritime safety management systems," Saf. Sci., vol. 109, pp. 109-129, 2018.

[4] Y. Dharma, "The effect of work motivation on the employee performance with organization citizenship behavior as intervening variable at Bank Aceh Syariah," in Proceedings of MICoMS 2017, Emerald Publishing Limited, 2018.

[5] M. Brury, "Pengaruh Kepemimpinan, Budaya Organisasi, Motivasi Kerja Dan Kepuasan Kerja Terhadap Kinerja Pegawai Pada Kantor SAR Sorong," J. Ris. Bisnis dan Manaj., vol. 4, no. 1, 2016.

[6] R. Rosmaini and H. Tanjung, "Pengaruh Kompetensi, Motivasi Dan Kepuasan Kerja Terhadap Kinerja Pegawai," Maneggio J. Ilm. Magister Manaj., vol. 2, no. 1, pp. 1-15, 2019.

[7] A. R. Ningsih, "Pengaruh Kepemimpinan Terhadap Motivasi Kerja Karyawan Pada PDAM Kota Madiun," Equilib. J. IIm. Ekon. dan Pembelajarannya, vol. 4, no. 2, pp. 192-200, 2016.

[8] E. B. Do Rêgo, W. G. Supartha, and N. N. K. Yasa, "Pengaruh Kepemimpinan Terhadap Motivasi dan Kinerja Karyawan pada Direktorat Jendral Administrasi dan Keuangan, Kementerian Estatal Timor Leste," E-Jurnal Ekon. dan Bisnis Univ. Udayana, vol. 6, no. 11, pp. 3731-3764, 2017.

[9] U. Rahardja, A. Moeins, and N. Lutfiani, "Leadership, competency, working motivation and paerformance of high private education lecturer with institution accreditation B: Area kopertis IV Banten province," Man India, vol. 97, no. 24, pp. 179-192, 2017.

[10] A. Bana, "Pengaruh Kepemimpinan Transformasional Dan Lingkungan Kerja Fisik Terhadap Kinerja Pegawai Dengan Motivasi Kerja Sebagai Variabel Pemediasi (Studi Pada Perusahaan Daerah Air Minum (Pdam), Kota Kendari).," J. Bisnis dan Manaj., vol. 3, no. 1, 2016.

[11] A. A. Sagita, H. Susilo, and M. Cahyo WS, "PENGARUH BUDAYA ORGANISASI TERHADAP KINERJA KARYAWAN DENGAN MOTIVASI KERJA SEBAGAI VARIABEL MEDIATOR (Studi Pada PT Astra Internasional, Tbk-Toyota (Auto2000) Cabang Sutoyo Malang," J. Adm. Bisnis, vol. 57, no. 1, pp. 73-82, 2018.

[12] J. Hom, B. Anong, K. B. Rii, L. K. Choi, and K. Zelina, "The Octave Allegro Method in Risk Management Assessment of Educational Institutions," Aptisi Trans. Technopreneursh., vol. 2, no. 2, pp. 167-179, 2020.

[13] S. Sudaryono, L. Sunarya, and G. Maulani, "Facility for Customizing Transaction Forms on Master Data Using an Online Accounting System Web For Work Efficiency Company," Aptisi Trans. Manag., vol. 1, no. 1, pp. 17-23, 2017.

[14] R. K. Wardani, M. D. Mukzam, and Y. Mayowan, "Pengaruh Budaya Organisasi Terhadap Kinerja Karyawan (Studi Pada Karyawan PT Karya Indah Buana Surabaya)," J. Adm. Bisnis, vol. 31, no. 1, pp. 58-65, 2016.

[15] B. M. Faturahman, "Kepemimpinan dalam budaya organisasi," MADANI J. Polit. dan Sos. Kemasyarakatan, vol. 10, no. 1, pp. 1-11, 2018.

[16] H. E. Sutrisno, Budaya organisasi. Prenada Media, 2019.

[17] S. Muhammad, "Pentingnya pengembangan budaya organisasi pada perguruan tinggi," J. IIm. WIDYA, vol. 4, no. 3, 2018.

[18] S. Purba et al., Perilaku Organisasi. Yayasan Kita Menulis, 2020.

[19] A. Nuryanti, "Pengaruh Budaya Organisasi Terhadap Kinerja Karyawan Pada Batik Brotoseno Sragen." Universitas Muhammadiyah Surakarta, 2016.

[20] I. M. Nurun Nabi and H. A. A. Dip TM, "Impact of motivation on employee performances: a case study of Karmasangsthan bank Limited, Bangladesh," Arab. J Bus Manag Rev., vol. 7, no. 293, p. 2, 2017.

[21] K. Khasanah, "The Effect of Lecturer Professionalism and Teaching Motivation on Lecturers Strengthening the Nation's Competitiveness (Survey on XYZ College Lecturers in Central Jakarta City)," ADI J. Recent Innov., vol. 2, no. 1 Sept, pp. 243-249, 2020.

[22] W. YETI, "ANALISIS FAKTOR DISIPLIN, MOTIVASI DAN KOMUNIKASI TERHADAP KINERJA KARYAWAN BAGIAN DALTIB (PENGENDALIAN DAN KETERTIBAN) DI DINAS PERHUBUNGAN KOTA SEMARANG," SKRIPSI, 2019.

[23] E. Dolan and A. S. Bein, "Implementation of Student Performance Management Guidance to Improve Quality Study at Colleges," IAIC Trans. Sustain. Digit. Innov., vol. 1, no. 2, pp. 160-171, 2020. 
[24] A. I. L. Wibowo, A. D. Putra, M. S. Dewi, and D. O. Radianto, "Study of Divergence of Go Public Company's Financial Performance Based on Website Before and After Merger Using Window Period Method TIME Frame 2015-2017," Aptisi Trans. Technopreneursh., vol. 1, no. 1, pp. 27-51, 2019.

[25] I. N. Mustika, "Pengaruh Kepuasan Kerja Dan Motivasi Kerja Terhadap Kinerja Karyawan Pada PT. Bpr. Picu Manunggal Sejahtera Denpasar," J. IImu Manaj., vol. 6, no. 1, 2016.

[26] A. A. T. Budianto and A. Katini, "Pengaruh lingkungan kerja terhadap kinerja pegawai pada PT Perusahaan Gas Negara (PERSERO) Tbk SBU Distribusi wilayah I Jakarta," Kreat. J. Ilm. Prodi Manaj. Univ. Pamulang, vol. 3, no. 1, 2017.

[27] Q. Aini, A. Alwiyah, and D. M. Putri, "Effectiveness of Installment Payment Management Using Recurring Scheduling to Cashier Performance," Aptisi Trans. Manag., vol. 3, no. 1, pp. 13-21, 2019.

[28] U. Rahardja, N. Lutfiani, A. S. Rafika, and E. P. Harahap, "Determinants of Lecturer Performance to Enhance Accreditation in Higher Education," in 2020 8th International Conference on Cyber and IT Service Management (CITSM), 2020, pp. 1-7.

[29] M. Sah and A. Chugh, "Performance Analysis of LTE system for 2x2 Rayleigh and Rician Fading Channel," Aptisi Trans. Technopreneursh., vol. 3, no. 1, pp. 13-22, 2021.

[30] S. Wahyono, A. K. Djaelani, and B. Wahono, "Pengaruh Lingkungan Kerja, Upah Serta Motivasi Kerja Terhadap Kinerja Karyawan Pada Pt. Sariguna Primatirta Tbk. Cikarang Jawa Barat," J. IIm. Ris. Manaj., vol. 10, no. 10, 2021.

[31] T. M. Ingarianti, "Pengembangan alat ukur komitmen organisasi," J. RAP (Riset Aktual Psikol. Univ. Negeri Padang), vol. 6, no. 1, pp. 80-91, 2017.

[32] I. Ghozali, "Aplikasi analisis multivariete dengan program IBM SPSS 23," 2018.

[33] S. Sudaryono, R. Rochmawati, N. Lutfiani, and U. Rahardja, "Strategy Enhancing Employee Reward Using the TOPSIS Method as a Decision Support System," IJCCS (Indonesian J. Comput. Cybern. Syst., vol. 14, no. 4.

[34] I. G. Riana, "Pengaruh budaya organisasi terhadap motivasi kerja dan kinerja karyawan Klumpu Bali Resort Sanur," 2017.

[35] S. Yuni, "Pengaruh Kepemimpinan Terhadap Kinerja Karyawan dengan Motivasi Sebagai Variabel Moderasi." Tesis, 2018. 